\title{
DE LAS LECTURAS DE ÉPOCA: INTENTIO AUCTORIS VERSUS INTENTIO OPERIS. SOBRE UN SONETO DE FRANCISCO DE ALDANA ${ }^{1}$
}

\author{
ON VINTAGE READINGS: INTENTIO AUCTORIS VERSUS INTENTIO OPERIS. \\ ABOUT A SONNET BY FRANCISCO DE ALDANA
}

\section{Rosa Eugenia MONTES DONCEL \\ Universidad de Extremadura rosamont@unex.es}

Resumen: El trabajo se centra en las llamadas "lecturas de época", en la dicotomía intentio auctoris / intentio operis acuñada por Umberto Eco y en las nociones de sensus litteralis y sensus spiritualis, así como en la dimensión ética de la Hermenéutica abordada entre otros por E. D. Hirsch. Para ejemplificar estos conceptos aduzco diversos textos de la literatura española que han sido objeto de exégesis anacrónicas y erradas, ya por sobreinterpretación ya por una lectura manquée. Finalmente recorro y analizo las distintas interpretaciones que se han hecho del soneto de Francisco de Aldana «Otro aquí no se ve que, frente a frente».

Palabras clave: Francisco de Aldana, debate intentio auctoris / intentio operis, misreading, lectura manquée, sobreinterpretación.

Abstract: This paper focuses on the so-called "Vintage Readings", on the dichotomy intentio auctoris / intentio operis coined by Umberto Eco and on the notions of sensus litteralis and sensus spiritualis, as well as on the ethical dimension of Hermeneutics addressed, among others, by E. D. Hirsch. To exemplify these concepts, I refer to various texts of Spanish literature that have been the object of anachronistic and erroneous exegesis, either by over-interpretation or by a manquée reading. Finally, I review and analyze the different interpretations of Francisco de Aldana's sonnet «Otro aquí no se ve que, frente a frente».

Key words: Francisco de Aldana, intentio auctoris / intentio operis debate, misreading, manquée reading, over-interpretation.

\footnotetext{
${ }^{1}$ La realización de este trabajo ha sido posible gracias al Proyecto de Investigación FFI2017-82101-P, financiado por el Ministerio de Ciencia, Innovación y Universidades. La autora pertenece al Instituto de Investigación LingLap.
} 


\section{1}

\section{De las lecturas erradas. La sobreinterpretación y la lectura manquée}

El casi desconocido poeta sevillano Andrés Fernández de Andrada culminó la serie de tercetos de su justamente conocida «Epístola moral a Fabio» con los cuatro versos siguientes:

Ya, dulce amigo, huyo y me retiro

de cuanto simple amé: rompí los lazos.

Ven y sabrás al grande fin que aspiro,

antes que el tiempo muera en nuestros brazos

(Fernández de Andrada, 2006: 85).

Y citando este cierre en su obra Historia, literatura, sociedad, que trata sobre problemas de interpretación literaria, señala José-Carlos Mainer que es lógico que el lector contemporáneo entienda la palabra brazos de forma metafórica. Sin embargo, añade este estudioso, "se ajusta mejor a la mentalidad del siglo XVII la concepción del tiempo como un fluido interiorizado que la objetivación de un bulto exento, como aconseja la lectura 'moderna' del poema" (Mainer, 2000: 25). Muy probablemente tanto el autor como los receptores coevos de la obra veían en brazos una metonimia de pulsos antes que una prosopopeya, metáfora o metonimia del individuo. Así parece indicarlo el recorrido por este campo metafórico en los múltiples veneros de los que bebió Andrada ${ }^{2}$. En cualquier caso la opción defendida por Mainer, en la estela de intérpretes previos, parece la más plausible ${ }^{3}$. Ahora bien, otra cuestión sería dirimir cuál de las dos resulte más feliz, y muchos lectores actuales pueden preferir la imagen de un tiempo personalizado que muere en brazos del hombre, inhábil para retenerlo, antes que la referencia a la muerte como cese del latir de nuestras venas.

Alleguemos otro ejemplo, más de una vez notado por la crítica, y anterior aún en varios siglos al de Andrada. El verso 235 del Poema de Mio Cid, que reza

\footnotetext{
${ }^{2}$ Precisamente Francisco de Aldana, principal objetivo de este artículo, nos proporciona ejemplos en que pulsos y brazos se hacen equivalentes. En «Pocos tercetos escritos a un amigo» observamos que los pulsos figuran como metonimia de manos, esto es, que, curiosamente, se verifica la misma identidad simbólica que aparecía en Fernández de Andrada pero en el sentido inverso al trazado por este: "Mientras andáis allá lascivamente, / con flores de azahar, con agua clara, / los pulsos refrescando, ojos y frente, / yo de honroso sudor cubro mi cara / y de sangre enemiga el brazo tiño / cuando con más furor muerte dispara" (Aldana, 2000: 289-290). No cabe dudar del profundo conocimiento que poseía Andrada de la obra de El Divino, puesto que este es, junto con Medrano, uno de los poetas españoles que más huellas constatables dejaron en la «Epístola moral a Fabio».

${ }^{3}$ Escriben Juan F. Alcina y Francisco Rico en los 90 en su estudio introductorio a la gran edición crítica del texto realizada por Dámaso Alonso en 1978: "La atrevida metáfora, la personificación gratuita que los modernos han querido reconocer debe ceder el puesto a una imagen más reglada, menos visionaria, pero no menos atractiva y grandiosa. Porque, leído a zaga de la tradición, el verso final cobra mayores dimensiones y entra más significativamente en la andadura del poema. El capitán Andrada exhortaba a Fabio y se exhortaba a sí mismo a vivir de conformidad con la naturaleza y a 'aprender a morir' (v. 83) [...]” (Fernández de Andrada, 2006: XVII-XVIII). Cumple empero recordar aquí que en el siglo XVII también podemos encontrar ejemplos en que efectivamente las manos del sujeto poético sostengan al tiempo de manera metafórica. Así en el soneto de senectute de Quevedo que principia con los versos « ¿Cómo de entre mis manos te resbalas! / ¡Oh, cómo te deslizas, edad mía!» (Quevedo, 1999: 186), donde late el tópico del tempus fugit asociado con el motivo del reloj de arena, que se halla sugerido por el verbo "resbalar".
} 
ha sido señalado como hontanar de los versos de Lorca que abren el «Romance de la pena negra» (vid., por ejemplo, Rodiek, 1995: 353, o Díez de Revenga, 2001-2002: 86):



(García Lorca, 1960: 364).

Pero, como ya he comentado en otro lugar, proponiendo un modelo de posible análisis deconstruccionista aplicado a esta filiación medieval del Romancero gitano,

[...] la metáfora de Lorca es mucho más osada (y más bella): las "piquetas de los gallos" funcionan como sujeto, "la aurora" como complemento directo. En el Poema de Mio Cid el verbo "quieren" no contiene un significado de voluntad; conforma con el infinitivo una perífrasis de incoación que vendría a decir: "están a punto de". "Albores", el equivalente semántico de "aurora", no es el objeto, sino el sujeto pospuesto, en disposición paralela con la cláusula anterior ("cantan los gallos"). Sin embargo, para el lector familiarizado con el poema lorquiano, al llegar a este verso le resulta casi imposible no recordar el texto contemporáneo, convertido [según la terminología acuñada por Harold Bloom en su etapa deconstruccionista] en nuevo "anfitrión" de tales palabras, y tendemos a leer automáticamente otorgando a los "gallos" la categoría de sujeto no solo de "cantar", sino también de "querer", confiriendo al verbo "querer" su valor pleno y a "albores" el papel de complemento, en suma convirtiendo en transitiva una oración que no lo era (Montes Doncel, 2008: 258).

Permítaseme solo ya, en esta muestra cronológicamente zigzagueante, saltar desde el origen de la poesía española a una de sus cimas barrocas, esta algo posterior a la gema de transición entre el Renacimiento y el Barroco que nos legó Fernández de Andrada (la epístola se fecha en 1610). Me refiero al celebérrimo soneto de Quevedo con justicia titulado por su editor González de Salas «Enseña cómo todas las cosas hablan de la muerte», publicado en su última versión en el Parnaso en 1648:

Miré los muros de la patria mía, si un tiempo fuertes ya desmoronados, de la carrera de la edad cansados, por quien caduca ya su valentía.

Salíme al campo. Vi que el sol bebía los arroyos del hielo desatados, y del monte quejosos los ganados que con sombras hurtó su luz al día.

Entré en mi casa. Vi que, amancillada, de anciana habitación era despojos; mi báculo más corvo y menos fuerte.

Vencida de la edad sentí mi espada, y no hallé cosa en que poner los ojos que no fuese el recuerdo de la muerte

(Quevedo, 1999: 184). 
Este poema ha generado un ejemplo ilustrativo y muy repetido de lectura manquée. Tanto en la edición de José María Pozuelo Yvancos (1999) como en el trabajo de María José Tobar Quintanar (2002) se relaciona a muchos de los numerosos intérpretes que lo han abordado (Buchanan, Ferraté, Blecua, Price, Wilson, Jauralde, Arellano y Schwartz, Rey Álvarez). Algunos de ellos, y probablemente el común de los lectores actuales no especializados, entienden el término "patria" en su recto sentido, y no como formante de una isotopía espacial simbólica que articula el soneto. Y de hecho, registramos incluso ejercicios intertextuales efectuados por poetas contemporáneos que se basan en esta lectura incorrecta, por ejemplo la composición «Como ciego miré» de José Agustín Goytisolo ${ }^{4}$.

Ya en 1979 Raúl Rodríguez, explorando el uso habitual del término "patria" en la obra de Quevedo e indagando en las abundantes fuentes eruditas manejadas por el autor, había concluido taxativamente:

El poema parte de una equivalencia metafórica entre el cuerpo y una edificación [...] de ningún modo existe posibilidad de una interpretación política. [...] en la poesía de Quevedo el término "patria" suele utilizarse metafóricamente con el sentido de lugar material y concreto de residencia [...]. Agustín.

Sabido es, por otro lado, que la imagen del cuerpo como patria del alma ya se encuentra en San

De todos modos, la interpretación de Blecua, asumida por Price, resulta parcial, por cuanto no es imprescindible que los "muros" hayan de ser "los de cualquier población española o francesa o italiana" (96) [...] el poeta no alude en el soneto a España, pero tampoco a ninguna ciudad; en este sentido, "patria" no es más que una variante de "casa" [...]. El poeta está describiendo una casa y, metafóricamente, un momento vital, física y psicológicamente, próximo al final definitivo (Rodríguez Rodríguez, 1979: 244-245)

Continuando en esta senda, María José Tobar Quintanar en su artículo de 2002 anota, acogiéndose a la acepción de patria como asiento recogida por Autoridades, que "[s]olamente en una ocasión de las trece registradas en los Índices de la poesía de Quevedo es posible que este autor atribuyera a patria su significado recto o denotativo de 'casa', sin aludir metafóricamente a otros términos" (Tobar Quintanar, 2002: 245). Si tenemos pues en cuenta el modus operandi del poeta, no parece coherente decantarse por la exégesis literal. Reproduce también Tobar las precisiones apuntadas por Jauralde y Blecua sobre el lugar de la producción quevedesca en que se sitúa el poema, cuya primera versión fue elaborada en 1613 y apareció en el Heráclito cristiano:

\footnotetext{
${ }^{4}$ Ignoro si la misreading es deliberada o fruto de una interpretación manquée, pero el contexto del poema revela palmariamente el valor denotativo que en él posee el término "patria": "Y de repente el aire / se desplomó encendido: / cayó como una espada / sobre la tierra. ¡Oh sí / recuerdo los clamores! // Entre el humo y la sangre / miré: miré los muros / de aquella patria mía. / Como ciego miré / por entre los escombros: / iba buscando un pecho / una palabra; algo / donde esconder el llanto. / Y encontré/ sólo muerte / ruina y crimen y muerte / bajo un cielo vacío" (Goytisolo, 2009: 95). Señala Martínez Fernández que José Agustín Goytisolo formula un intertexto con sustitución de elementos mediales (Martínez Fernández, 2001: 106). Se recrea el conocido episodio biográfico del bombardeo en que murió la madre de los hermanos Goytisolo y que estos, nada reacios a la falacia patética, incorporaron a sus mundos de ficción. En el soneto de Quevedo la palabra muerte era la última, y aquí aflora asimismo hacia el final del texto, pero evidentemente no en referencia a la del sujeto lírico.

${ }^{5}$ Lastimosamente este aclaratorio artículo se halla deturpado por muchas y graves erratas, algunas de ellas en el cuerpo de los textos de Quevedo. La entrada de José Manuel Blecua en Raúl Rodríguez es la siguiente: «Sobre un soneto de Quevedo», en Sobre el rigor poético en España y otros ensayos, Barcelona, Ariel, 1977, pp. 91-98. Existen de este trabajo versiones distintas y alguna anterior a la citada por Rodríguez.
} 
Jauralde, 1998, p. 296: "El conjunto de poemas, por tanto, se distribuye claramente en dos grupos: los de inspiración religiosa y los que merodean insistentemente en torno al tema de la muerte y la vanidad de los bienes terrenos, incluyendo la propia presencia física, el cuerpo". Por su parte, Blecua, 1978, p. 289, resaltó el valor significativo de la colocación del soneto entre «Ven ya, miedo de fuertes y de sabios» y «iCómo de entre mis manos te resbalas!» en el manuscrito del Cancionero de 1628: "Reléase el soneto junto con los dos anteriores y se verá la perfecta unidad de clima poético que los motiva. Nada más lejos de una intención política, imposible en 1613" (Tobar Quintanar, 2002: 247n) ${ }^{6}$.

María José Tobar, aunque cautelosa y refractaria a las posiciones categóricas, defiende por supuesto el desempeño de la metáfora arquitectónica de aquilatado arraigo en Quevedo, si bien postula argumentadamente, en la línea de Ricardo Senabre (apud Pozuelo, 1999: 132n) que "patria" no equivale a "casa", sino a "alma"7. En definitiva, una exégesis de "patria" en su acepción literal solo puede atribuirse a la carencia de competencia lectora, que diría Eco. En este caso, en primer lugar, a la ignorancia de la tradición clásica, sobre todo senequista y ovidiana, de la que se nutre Quevedo, así como al desconocimiento del antiquísimo y pródigo tópico espacial que identifica la casa con el individuo. Rastreable desde la Biblia y los Santos Padres hasta la mística, pasando por la lírica cancioneril y popular, su cultivo fue ubérrimo en el siglo pasado, especialmente en el surrealismo, y se mantiene vigente en nuestros días. En segundo lugar, los críticos que interpretasen como literales esos "muros de la patria" habrían incurrido en la avilantez de realizar un análisis inmanente en el peor sentido del término, es decir, de leer con orejeras, de lanzar una interpretación de un texto sin consultar, siquiera de forma sumaria, el resto de la obra del autor y sus temas recurrentes.

Los tres ejemplos aducidos corresponden a metáforas puras, y los casos de misreading (la voz inglesa ha triunfado en un sentido generalizador) que he ido señalando constituirían bien una sobreinterpretación o Überinterpretation (si nos servimos de la feliz acuñación alemana), bien una lectura manquée (aquí se ha impuesto el término galo). Dicho con otras palabras, el receptor puede descodificar aberrantemente un texto porque ve un significado simbólico donde no lo hay o porque es incapaz de ver el significado simbólico donde sí lo hay. De este modo, el lector moderno que realiza una interpretación anacrónica de la «Epístola moral a Fabio» aprehende en "brazos" una metáfora que no existe, mientras que el análisis incorrecto del poema de Quevedo lee "patria” en su recto sentido y no percibe que se trata de una metáfora del individuo. El fenómeno de la lectura errónea del verso citado del Mio Cid, condicionada por la difusión del Romancero gitano, se adscribiría también al terreno de la interpretación excesiva, pues si en cualquier caso el verbo "romper" está utilizado figuradamente, la metáfora que resulta de considerar "gallos" como sujeto es más original y desplazada, en definitiva más "moderna", que la que otorga la categoría de sujeto a los "albores".

\footnotetext{
${ }^{6}$ En la misma dirección, y más tajantemente, abundaba Pozuelo Yvancos: “[la versión primitiva del Heráclito] resulta muy útil para aclarar el sentido literal del soneto y sobre todo para corregir la frecuente lectura del mismo en una clave política, aquella que ha pensado que con los muros desmoronados de la patria había una referencia a la decadencia de España, lo que la 'caduca valentía' de la versión de 1648 podía admitir, pero que 'la obediencia al tiempo en muerte fría' aclara como referido directamente al cuerpo del poeta vencido por la carrera de la edad y por la vejez” (Pozuelo Yvancos, 1999: 132n). 7 “[...] si se atribuye al sintagma los muros de la patria mía la interpretación de 'casa' como cuerpo, Quevedo habría repetido la misma alusión en muros (que por sinécdoque remiten ya a la casa y se utilizaron como metáfora del cuerpo en los poemas 145, v. 264 y 31, v. 5) y patria (en uso figurado de su acepción como 'casa'). / Esta hipótesis no nos parece muy probable" (Tobar Quintanar, 2002: 254).
} 
En los modelos aportados, como digo, la misreading opera en el predio de la metáfora que pudiéramos llamar tradicional o sustitutiva, empleada en lírica con mucha mayor profusión que en los otros géneros, incardinada en el estadio de la elocución y pura (no parece lógico que una metáfora in praesentia suscite tales problemas, ya que el término real se halla explícito en el propio texto) ${ }^{8}$. Pero la lectura aberrante puede afectar, además de a imágenes del tipo que hemos visto, a todos los órdenes interpretativos, por ejemplo a la metáfora diegética o a la actualización de elipsis. La primera, definida por Genette y presente sobre todo en textos narrativos, compete a un estatus más estructural que estilístico (Genette, 1989: 70). La metáfora diegética no consiste en sustituir un elemento significativo por otro, sino, grosso modo, en sumar un significado simbólico a un constituyente que ya funciona en el nivel literal.

Acudamos a un ejemplo muy sencillo de la literatura española, tomado de la novela Réquiem por un campesino español de Sender: Mosén Millán aguarda en la sacristía para celebrar una misa de difuntos por Paco el del Molino, fusilado un año antes; mientras, el potro blanco de Paco, que galopa desbocado por las calles de la aldea, llega incluso a entrar en la iglesia, de donde es expulsado no sin esfuerzo por los tres enemigos de Paco, que son los únicos lugareños asistentes al oficio religioso (Sender, 2018: 137-139). En lo tocante al contenido manifiesto el caballo de Paco penetra efectivamente en el templo el día de la misa de réquiem, motivo que se justifica en la coordenada de la verosimilitud porque los familiares de Paco, enfermos o consternados, tienen desatendidos sus animales y su escasa hacienda. Pero estaría realizando una lectura manquée aquel receptor que no se apercibiese de que este animal, joven y vigoroso, como lo era Paco al morir; noble y difícilmente domeñable, y además blanco, esto es, puro, como íntegro era Paco, constituye la representación de ese protagonista muerto que sigue aún simbólicamente presente para los habitantes de la aldea ${ }^{9}$. La diferencia radica en que, al tratarse de una metáfora diegética, dicha lectura, limitada al plano superficial, sería incompleta y reductora, pero no aberrante, como sí lo es la que soslaya el haz simbólico en el caso de una metáfora "ordinaria" pura, la "patria mía" quevedesca, pues a la luz de tal interpretación se tornarían incoherentes o incomprensibles otras partes del texto (vid. supra, nota 6). Sobre este punto, y glosando a San Agustín en De Doctrina Christiana, afirmaba Umberto Eco en I limiti dell'interpretazione:

[...] si una interpretación parece plausible en un determinado punto de un texto, sólo puede ser aceptada si es confirmada - o, al menos, si no es puesta en tela de juicio- por otro punto del texto. Esto es lo que entiendo por intentio operis [...]. La iniciativa del lector consiste en formular una conjetura sobre la intentio operis. [...] Pero, al final, las conjeturas deberán ser probadas sobre la coherencia del texto, y la coherencia textual no podrá sino desaprobar algunas conjeturas aventuradas (Eco, 1992: 41).

\footnotetext{
${ }^{8}$ Aunque el asunto aquí no puede ser abordado sino esquemáticamente, cito algunas definiciones de metáfora básica que contribuyan a esclarecer lo expuesto. Para Mortara Garavelli es la "sustitución de una palabra por otra cuyo sentido literal posee cierta semejanza con el sentido literal de la palabra sustituida” (Mortara Garavelli, 1991: 181). Y según Ana María Platas Tasende la metáfora tradicional "[c]onsiste en trasladar el sentido propio de un término (término real, TR) a otro con el que se relaciona por semejanza semántica (término imaginario, TI). Su forma más perfecta es la metáfora pura o metáfora in absentia, en la que solo figura el TI y ha de deducirse el TR" (Platas Tasende, 2011: 404).

${ }^{9}$ Es una imagen afortunada y fácil de descodificar. Ya en las primeras páginas del relato se decía: "El cura seguía pensando que aquel potro, por las calles, era una alusión constante a Paco y al recuerdo de su desdicha" (Sender, 2018: 72). Vid. Villanueva, 1994: 336.
} 
También son, como he dicho, objetivos susceptibles de misreading las elipsis y huecos (los llamados lücken por Roman Ingarden) que requieren ser actualizados, es decir, que demandan una labor de "relleno" por parte del lector, y que ofrecen claves para llevar a cabo dicha operación en uno u otro sentido ${ }^{10}$. Puede tratarse de cualquier género de elipsis, ya un salto temporal, ya una omisión de otra especie ${ }^{11}$. Por seguir con la misma novela: hay un crítico, Carlos Campa Marcé, que propuso hace no muchos años la hipótesis de que Paco el del Molino era hijo de Mosén Millán (Campa Marcé, 2009). Para argumentarla apela a una ironía emitida por el padre de Paco sobre su paternidad el día del bautizo del niño, y reúne todas las escasas menciones a la madre de Paco que aparecen en la novela, no mucho más numerosas que las que se contabilizan de su marido, y el dato de que fuera ella, y no otro miembro de la familia, quien acudiese al sacerdote a la hora de impetrar ayuda para su hijo. Asimismo recopila las referencias a Mosén Millán como padre y las ocasiones en que este llama hijo a su monaguillo. Si todos los "indicios", por llamarlos de algún modo, son febles, qué decir de este último: lo verdaderamente significativo sería hallar un cura al que nadie se dirija como padre, y que a su vez no llame nunca hijos a sus feligreses, máxime si son mucho más jóvenes que él.

El propio autor califica su propuesta de "muy osada" y alguna vez teme estar rizando "el rizo de la interpretación". En primer lugar, si el sacerdote fuese el padre de Paco quedarían desequilibrados otros puntales metafóricos de esta novela breve, densa y marcadamente barroca. Es obvio, y no hago más que repetir lo que diversos especialistas han dicho ya, que Sender quiere personificar en Mosén Millán al estamento clerical, y trazar un paralelismo entre su participación en la tragedia de Paco y el papel que, en opinión del autor, ejerció la Iglesia española en la Guerra Civil (acontecimiento histórico nunca explícitamente llamado por su nombre en la obra); de la misma forma, “[...] como bien a las claras da a entender el segundo título de la obra, Paco es el símbolo del campesinado y, en definitiva, del pueblo" (Villanueva, 1994: 340). Si el deuteragonista no fuese solo "el bienintencionado cura de la aldea, amigo de Paco", ya no estaríamos ante una novela social, sino tal vez ante un drama psicológico o de otra clase, y la trascendencia simbólica del sacerdote quedaría harto desvaída. ¿Por qué iba a querer el autor hacer esto? Y, si lo hubiese querido, ¿por qué no lo sugirió? Con símbolos nada abstrusos, verbigracia el del caballo, Sender se sirvió como hemos visto de indicadores explícitos. Nada hay en el texto que autorice la interpretación de Campa, y ni aun fuera de la inmanencia del texto cita este crítico declaraciones de Sender o datos biográficos o ecdóticos que pudieran avalarla. Además, la "calumnia" vertida sobre Mosén Millán no rellena en puridad ningún hueco, puesto que la novela no plantea interrogante alguno sobre la paternidad del protagonista; pero en cualquier caso, la razón por la que la considero indigna de ser tenida en cuenta no es esta; ni siquiera - aunque reputo este factor mucho más importante- - porque distorsione la coherencia ideológica de la novela, pues obras hay que albergan soluciones incoherentes: me parece rechazable por el hecho de que los detalles

\footnotetext{
${ }^{10}$ Estos "huecos" definidos desde la Fenomenología por Ingarden (1989: 48) constituyen claros precedentes de los blacks o "vacíos" acuñados por Iser, teórico de la Estética de la Recepción nacida en el seno de la Universidad de Constanza en los años 70 del pasado siglo.

${ }^{11}$ Sobre la naturaleza y categorías de la elipsis remito a mis trabajos de 2000 y 2016.
} 
aportados son sencillamente inanes, y no justificables ni en una tradición literaria ni en su ilación en el texto. La propuesta no puede en modo alguno imputarse a la intentio auctoris, y localizarla en la intentio operis, esto es, lanzar al aire una cuestión de la índole de: "pero ¿y si Mosén fuera el padre de Paco?" atenta en primer lugar contra la "economía isotópica”. Este concepto, acuñado por Eco (Eco, 1992: 117 y ss.), consiste, expresémoslo de manera pedestre, en que "el crítico sepa lo que va buscando" y no se malgaste corriendo en pos de lo que no es probable que exista; pero en segundo lugar, en el plano de la ficción, estas preguntas, del tipo de qué vida matrimonial aguardaba a la Cenicienta y el Príncipe o qué clase de infancia tuvo Hamlet, incurren en el equívoco de confundir a los personajes literarios con personas. En consecuencia encaran el estudio de estos como si fueran entes reales cuyas vidas y circunstancias se extendieran más allá de la fracción de mundo ficticio que aparece —o se sugiere — en la obra. El teórico Lubomir Doležel condenaba muy lúcidamente tales prácticas de pseudomímesis ${ }^{12}$.

Este mismo motivo, la filiación bastarda, se ofrece en Bearn o la sala de las muñecas, de Lorenzo Villalonga, pero en esta ocasión sí presentado como enigma: el propio narrador homodiegético Juan Mayol manifiesta no tener recuerdos de sus sedicentes padres campesinos, y no comprender del todo los sentimientos que el señor de Bearn muestra hacia él, ni los celos que él a su vez experimenta hacia Jaime, el otro niño prohijado por don Antonio $^{13}$. En ningún momento de la obra, de condición indiscutiblemente abierta y merecedora de más interés que el que la crítica le ha venido dispensando, hallaremos una respuesta expresa a este ni a otros misterios planteados, el principal de ellos contenido hasta en el paratexto; sin embargo Villalonga deja caer abundantes datos que carecerían de sentido si el inocauto capellán no fuese, en efecto, hijo ilegítimo de su patrón ${ }^{14}$.

En cambio El Buscón no abre ningún "misterio que resolver" sobre la prosapia de don Diego Coronel, y a pesar de ello Quevedo salpica su discurso de alquitarados pormenores que podrían incluso ser pasados por alto en una primera lectura por un receptor del siglo XXI; pero no pueden tener otro objeto, sobre todo si los consideramos en su conjunto, que el de conducirnos a una conclusión nunca explícita en el texto mas irrefragable tras su escrutinio: a saber, que el rico caballero don Diego Coronel es tan judeoconverso como su criado Pablos. Al margen de que Quevedo diera rienda suelta a su antisemitismo en muchos otros de sus escritos literarios, especialmente en la poesía satírica, en lo concerniente a El Buscón fue Augustin Redondo, que yo sepa, el primero que vio y agavilló ya en 1971 señales como las que a continuación enumero: Coronel era el apellido de una famosa familia segoviana de judeoconversos; Diego y Pablos asisten a la misma escuela porque ambos vivían en la misma zona;

\footnotetext{
12 "[la pseudomímesis] se basa en la presuposición de que los dominios de la ficción en general y las mentes ficcionales en particular existen independientemente del acto de representación, a la espera de ser descubiertos y descritos" (Doležel, 1997: 76).

${ }^{13}$ He aquí un ejemplo: “-Demonio —exclamó el señor, tirándome de una oreja-, eres muy joven para sacar consecuencias con esta seguridad. / Pero yo notaba, sin saber a qué achacarlo, que aquella seguridad le satisfacía. Le gustaba también, y ponía en ello una vanidad extraña, que me criara esbelto y robusto" (Villalonga, 1985: 82. Subrayado mío).

${ }^{14}$ Vid. fragmentos significativos en 62, 63, 69, 77, 78 u 82. Sobre la capacidad sugeridora de Bearn vid. Montes Doncel, 2006: 199 .
} 
los patronímicos de nombres de animales solían ser adoptados por judíos, de modo que el dómine Cabra probablemente lo sería y los Coronel enviaron a su hijo a formarse con él; la tía de doña Ana, prima de don Diego, a despecho de la nobleza y hermosura de la joven se apresura a concertar para ella una boda con un absoluto desconocido, sin preocuparse siquiera por investigar el linaje de este. Y aunque la novia era bella en su prosopografía no se prescinde siquiera del tópico rasgo de una "buena nariz" (Quevedo, 2001: 147). Algunos comentarios son más sutiles, como ese de que doña Ana "corría peligro en tiempo de Herodes, por inocente" (Quevedo, 2001: 147), siendo así que solo niños judios (y cabría apostillar que únicamente los varones) corrieron peligro en tiempo de Herodes, aunque el lector apresurado pudiese quedarse sin más con la información sobre la inocencia, que se ha leído también irónicamente en el sentido de estulticia. Del mismo modo, y como dice Vincent Parello (Parello, 2007: 113) en su estudio sobre el tema, siguiendo a Cross, las palabras "no debe a nadie en sangre" (Quevedo, 2001: 144) referidas a doña Ana son ambivalentemente irónicas. Cabría interpretar que la joven no es inferior a nadie en alcurnia, pero también que no debe nada a sus antepasados puesto que ellos no le legaron sangre limpia. La familia Coronel ha comprado su nobleza con dinero.

Una lectura actual puede adolecer aquí de miopía interpretativa, por así llamarla, más fácilmente que una contemporánea al texto. Es improbable que al receptor del siglo XVII le pasara desapercibida la inverosimilitud de que una familia noble, y no carente de recursos, se conduzca con la precipitación con que lo hace la de doña Ana a la hora de casar a esta con un tal Filipe Tristán al que acaba de conocer. Y además de la etopeya negativa que recibe la figura de don Diego, también es revelador que en las ocasiones en que él o sus secuaces lanzan pullas a Pablos nunca mienten su condición de judeoconverso, toda vez que este habría sido el recurso más fácil para arrojar sobre él un baldón. Por ello, aunque la propia novela no contenga un interrogante, una elipsis marcada, explícita, el intérprete incapacitado para hilvanar esos hilos y deducir que la familia Coronel es de ascendencia judía estará llevando a cabo una lectura sesgada ${ }^{15}$; lo es necesariamente toda aquella que no se percata de las ironías, sean del género que sean, que, efectiva y deliberadamente, el autor vertió en su discurso. En este caso, en que la elipsis no tiene rango temporal, convendría utilizar la terminología de Genette, que titula a dichas omisiones paralipsis: "Ejemplo contundente: la ocultación por Stendhal, en Armadance, mediante tantos seudomonólogos del héroe, de su pensamiento central, que, evidentemente, no puede ser otro que su impotencia sexual" (Genette, 1989: 250). Bien es verdad, desde el punto de vista de la justificación focal, que Octave no puede ignorar tal información, mientras que Pablos podría desconocer los orígenes judíos de don Diego, y actuar en este sentido como narrador teóricamente ingenuo ${ }^{16}$. En cualquier caso, colegimos que el texto de El Buscón (Booth diría: su autor implícito) escamotea ex profeso al lector un dato cardinal para su correcto descifrado. No es "económico", no

\footnotetext{
${ }^{15}$ Garrido Domínguez daba el nombre de explícitas a las elipsis que, a diferencia de las implícitas y las hipotéticas, "cuentan con signos en el texto" (Garrido Domínguez, 1993: 179). Considero pertinente la designación siempre que advirtamos que este autor circunscribía el fenómeno al ámbito temporal, que no es el que ahora atendemos.

${ }^{16}$ Entidad analizada por Wayne C. Booth (1974).
} 
procede preguntarse si Paco el del Molino era hijo de Mosén Millán, pero sí procede inquirir si los Coronel eran cristianos viejos ${ }^{17}$.

\section{Intentio auctoris e intentio operis. De la legitimidad o ilegitimidad de la lectura errada. Dimensión ética}

Las interpretaciones fallidas en los ejemplos de lírica que he presentado, así como la recepción actualizada y manquée de El Buscón, obedecerían en todos los casos a las dificultades del intérprete de salvar la distancia temporal (lo cual quiere decir cultural y lingüística) que lo separa del momento de la emisión, y de alcanzar el sensus litteralis o filológico, en última instancia la intención del autor ${ }^{18}$.

Estas misreadings constituirían pues muestras de sensus spiritualis, de lecturas de época, aunque no toda lectura de época ha de ser necesariamente fallida; antes bien, la exégesis dilatada en el tiempo puede enriquecerse por la posesión del bagaje que tradición y canon hayan ido incorporando. Es indudable que al enfrentarnos al análisis de un texto no contemporáneo tenemos ventajas y desventajas respecto a sus receptores coevos y que, en general, pesan más las últimas: existen referencias y elementos históricos y culturales de intrincada si no imposible recuperación, escollo que por supuesto no debe disuadir al crítico de acometer el estudio. Entre las ventajas, no es la menor la posibilidad de acceder a mundos y mentalidades distintos del nuestro, por no hablar de que la distancia emanada de la evolución lingüística aumenta el extrañamiento, y, con él, una belleza formal en la esfera de la aesthesis o placer estético del receptor que no procede de la intentio auctoris ni posee por ende un correlato en la poiesis o acto creativo. Sirva el más simple de los ejemplos, un poemita extraído de nuestro cancionero tradicional:

\section{Ojos de la mi señora, y vos, ¿qué habedes? ¿por qué vos abaxades cuando me veedes?}

(Alín, 1991: 83) ${ }^{19}$.

El ser humano tiene un universo previo (el Welt de Heidegger), unos "prejuicios", en definitiva unos condicionamientos históricos y personales que lo incapacitan para entender completamente a otro ser humano, para ser objetivo. Poseemos nuestra cadena de recuerdos y no podemos sustituirla por

\footnotetext{
${ }^{17}$ La duda esencial que la lectura de La Celestina le suscita a cualquier receptor de hoy es, por supuesto y como comenta Becerra Mayor: “¿Por qué Melibea y Calisto no se casan?” (Becerra Mayor, 2006: 33). ¿Existe entre ellos alguna diferencia social que dificulte su unión? Ninguna de las múltiples respuestas que hasta la fecha han barajado conspicuos historiadores de la literatura o sociólogos, relacionados por Becerra, resulta concluyente. ¿Conocerían la razón los lectores del siglo $\mathrm{XVI}$ ¿ ¿O sencillamente la obra peca en este punto de incoherencia?

${ }^{18}$ En Réquiem por un campesino español, por su parte, la Überinterpretation ejecutaba sencillamente una de esas hipótesis de demostración o refutación imposible y por lo mismo estériles. Booth comentaría irónicamente que en esas ocasiones "[g]ana el crítico con el más grande poder persuasivo, y para algunos lectores esto significa, simplemente, el crítico que puede hallar más ambigüedades o ironías" (1974: 350).

${ }^{19}$ Aun cuando el pronombre vos tiene por antecedente no ya a un pronombre de segunda persona del singular, sino al sustantivo plural ojos, que funciona como personificación o metonimia del "tú", es probable que incluso entre los lectores actuales estos versos resulten más líricos y armoniosos, por más extraños, para un hablante español que para uno hispanoamericano acostumbrado al voseo.
} 
otra; leemos desde el siglo XXI y no podemos leer desde otro lugar, enfrentados a ese "espesor de los siglos" de que hablaba Zumthor. Puesto que cada crítico es portador de un espíritu (Geist) individual, ¿hemos de admitir que existen tantas lecturas válidas como lectores, según parece presumir el relativismo imperante? Félix Martínez Bonati llega a plantear, y debo esta cita a la erudición de la Profesora $\mathrm{M}^{\mathrm{a}}$ Luisa Burguera, que "el mensaje literario no es un mensaje enteramente consciente e intencional; que su finalidad es, hasta cierto punto, secreta (en parte ignorada por emisor y receptor)" (Martínez Bonati, 1987: 76). El crítico chileno cita al Sócrates del Ion y a Schelling y Hegel como precursores de esta consideración de un arte creativo "parcialmente inconsciente".

Dentro de la Hermenéutica o antigua ciencia de la interpretación -interpretación sensu lato de cualquier tipo de texto y no solo de los literarios - muy tempranamente se erigieron dos tendencias a menudo enfrentadas, la intencional-histórica y la alegórica-anacrónica: la primera de ellas predomina en etapas como el Renacimiento y el Romanticismo, la segunda se encarna especialmente en la Edad Media. No solo la exégesis, sino la cultura medieval en su conjunto es toda ella proclive al anacronismo, a pasar por el filtro de su propio canon elementos y conceptos de otras épocas. Sirvan de elemental ilustración las muchas obras de arte medievales en que los personajes bíblicos aparecen vestidos a la manera del Medievo (si bien es cierto que el fenómeno no se restringe a la Edad Media). El enfoque literal, por el contrario, está interesado en la intención del autor y para llegar a ella recurre a la competencia filológica. ¿Qué significaban los términos en el estado de lengua y en el contexto en que se produjo la obra? El problema del historicismo versus anacronismo ha gravitado desde siempre sobre la Hermenéutica. Asevera E. D. Hirsch:

Aunque ya no apuntalamos nuestro historicismo con tales ideas cuasi-religiosas [las románticas], el ideal romántico de pluralismo cultural ha continuado siendo la norma ética dominante de la interpretación durante la mayor parte de los siglos XIX y XX: es más general y humanista abarcar la pluralidad de culturas que ser prisioneros de la propia. Así pues, deberíamos respetar el sentido original como el mejor sentido, como la norma más legítima para la interpretación. Hace bien poco el historicismo ha girado sobre sí mismo para anunciar que somos prisioneros, se quiera o no, de nuestra propia cultura y que, por tanto, debemos volver a una idea cuasi-medieval de la interpretación; es decir, el mejor sentido (cualquier sentido a este respecto) debe ser anacrónico, nos guste o no. Desde este punto de vista reciente, el "mejor sentido" se revela como una elección ética y consciente en relación con lo que es mejor "para nosotros hoy en día", de acuerdo con algún criterio incontestable en nuestras circunstancias históricas presentes (E. D. Hirsch, 1997: 142).

Hirsch encuentra explicable la supuesta contradicción de que el Romanticismo más vehemente se rija por el sensus litteralis en detrimento de la libertad de lecturas: Schleiermacher opinaba que toda interpretación de un texto había de basarse en el dominio linguiístico común al autor y al público original $^{20}$. Para Hirsch, los teóricos románticos alemanes han llegado a este "rigor" sorprendente por su sublimación de la tesis "policultural" según la cual en la cultura originaria del texto radica siempre la mejor interpretación. Dicho de manera simple, la Hermenéutica romántica salva la aporía de la

\footnotetext{
${ }^{20}$ Encontramos transferido este mismo debate en la copiosísima bibliografía que ha surgido en las últimas décadas sobre la teoría de la traducción. La tendencia actual mayoritaria en este terreno, en contraposición con lo que ocurre en la parcela hermenéutica, opta por seguir los dictados del teórico de Iena (Schleirmacher, 2000), es decir, por que el traductor trate de acercarse a la cultura de la LO (lengua original) y no, a la inversa, de aproximar el texto traducido a la LT (lengua terminal). Vid. Montes Doncel y Rebollo Ávalos, 2008: 156.
} 
distancia "lingüística" que separa a dos seres humanos que se comunican —el lector y su intérpreteprecisamente en la creencia de una comunión o afinidad entre los espíritus humanos. De ahí la importancia otorgada a las nociones de sympatheia y "congenialidad" (de índole tan romántica), que han de mediar entre el crítico y el escritor, aunque no por ellas olvidaba Schleiermacher la presencia de "lo extraño".

Los exegetas medievales se decantan por la vía segunda en el convencimiento de la preeminencia de lo religioso. Tanto historicistas como alegoristas o anagógicos buscan la "mejor interpretación", y las disidencias estriban, ya lo dice Hirsch, en decidir qué cosa sea la mejor y según qué criterio. ¿Lo mejor para qué o para quién? ¿Para el autor? ¿Para el lector? ¿Lo mejor en aras de la moral? ¿Lo mejor en aras de un objetivo estético?

El texto reproducido de Hirsch plantea un debate muy vigente en la teoría literaria contemporánea: la imposibilidad de sustraernos de nuestro contexto histórico para investir plenamente el argumento intencional, gramatical, filológico. El deseo y la viabilidad de ser objetivos constituyen a mi entender el problema axial de los críticos literarios, y el pirronismo se ha enseñoreado de la teoría literaria de buena parte del siglo XX y de los lustros transcurridos del XXI. Cierto es que el siglo pasado se inaugura con movimientos que reaccionan contra la crítica historicista o impresionista del XIX, el idealismo de un Croce o el biografismo de Saint-Beuve: así ocurre en el formalismo ruso por descontado, mientras que desde Estados Unidos el New Criticism, partidario de la close reading, reprueba la "falacia intencional" de la orientación genética, pero no menos que la "falacia afectiva" centrada en el receptor, que confunde el poema con sus resultados (Wimsatt y Beardsley, 1954). Más tarde, y aunque enraizada en el idealismo en su concepción de literatura y en sus desiderata, la Estilística provee al crítico de una metodología rigurosa, filológica y primordialmente interesada por la intentio auctoris, como rigurosa es también la epistemología estructuralista, esta por su parte virada hacia la intentio operis ${ }^{21}$.

Sin embargo, también en el pasado siglo, la revitalización de las teorías psicoanalíticas y marxistas y la emergencia de las corrientes englobadas bajo el marchamo del postestructuralismo y el posmodernismo, entre ellas singularmente la deconstruccionista y, aunque en menor medida, la Estética de la Recepción, supondrán la apertura al escepticismo y subjetivismo hermenéuticos en los que seguimos inmersos a día de hoy. Nuestra sociedad propende a la actualización, como la medieval, y resulta fuertemente ideologizada la ontología del hecho literario que se socava de los movimientos revisionistas del canon, el feminismo, el postcolonialismo, el nuevo historicismo, la ecocrítica, etcétera; estos componen ya poéticas más preceptivas que descriptivas, si bien las últimas aportaciones

\footnotetext{
${ }^{21}$ El enfrentamiento entre Raymond Picard y Roland Barthes a propósito de Racine (Barthes, 1963) constituye sin duda uno de los más notorios exponentes de la dicotomía intentio auctoris / intentio operis y materializa la posición adoptada al respecto por el estructuralismo. Picard, considerado uno de los máximos especialistas en la obra del dramaturgo francés, se yergue en adalid de la intentio auctoris y ataca el Sur Racine de Barthes en Nouvelle critique ou nouvelle imposture, (Picard, 1965). Barthes replica al año siguiente en Critique et verité (Barthes, 1966), y, convertido a su vez en corifeo de la intentio operis, propugnará "la muerte del autor" en su famoso artículo de 1967 (Barthes, 1977).
} 
de la disciplina hermenéutica parecieran buscar un término medio entre las dos nociones extremas de interpretación ${ }^{22}$.

Es Umberto Eco en I limiti dell'interpretazione, especialmente en su primer capítulo ( Intentio lectoris. Apuntes sobre la semiótica de la Recepción»; 1992: 21-46), quien suministra la terminología del afortunado binomio intentio auctoris / intentio operis, muy relacionado con el de "interpretación objetiva" / "interpretación subjetiva", pero que a mi entender cataliza un debate más concreto y fecundo $^{23}$. En fechas recientes, por ejemplo, Alfonso Martín Jiménez ha defendido el desdoblamiento de la intentio auctoris en una posible "intención manifiesta" y una "intención encubierta", que proyecta al estudio de los Quijotes de Cervantes y Avellaneda en cuanto portadores de determinados mensajes cifrados solo para algunos lectores (Martín Jiménez, 2014). Los romans à clef serían en general representativos de tal estrategia.

Respecto al otro punto, pues, no ya a la posibilidad, sino al prurito de objetividad que debería presidir la actividad crítica, cabe recurrir, al margen de criterios científicos y estéticos, al planteamiento moral. Si consideramos herético que se tergiversen las palabras de la Biblia, fraudulento el que se tergiversen las palabras de la ley, falaz y mezquino el que se tergiversen las palabras de cualquier persona, ¿por qué ha de ser admisible en cambio que se tergiversen las palabras de Andrada, Quevedo o Sender? Nuevamente recurro a un fragmento del opúsculo de Hirsch:

La mera preferencia individual no debería ser un valor tan primordial, ni tampoco las meras preferencias de muchas personas. [...] Cuando utilizamos simplemente las palabras de un autor para nuestros propios propósitos sin respetar su intención, transgredimos lo que Charles Stevenson, en otro contexto, llamó "la ética del lenguaje", del mismo modo que transgredimos las normas éticas cuando utilizamos a otra persona únicamente para nuestros propios fines. Kant sostenía como fundamento de la acción moral que debía considerarse a los hombres como fines en sí mismos, y no como instrumentos de otros hombres. Este precepto es transferible a las palabras de los hombres porque el habla es un ámbito social, y también porque cuando no logramos asociar las intenciones de un hombre con sus palabras perdemos el alma del habla, que consiste en transmitir sentido y comprender lo que se intenta transmitir.

No me convence la idea de que este imperativo ético del habla, al que todos nosotros nos sometemos en el discurso ordinario, no es aplicable al habla escrita o, en particular, a textos literarios. [...] la ética del lenguaje tiene validez para todos los usos del leguaje, oral y escrito, tanto en poesía como en filosofía (Hirsch, 1997: 157. Subrayado mío).

En la misma órbita se situaba Eco al distinguir entre interpretación y uso del texto. Respecto a «La carta robada» de Poe, "la de Derrida era interpretación mientras que lo de Maria Bonaparte, que usaba el texto para sacar inferencias sobre la vida privada de Poe, introduciendo en el discurso pruebas que obtenía de informaciones biográficas extratextuales, era simple uso" (Eco, 1992: 39).

\footnotetext{
${ }^{22}$ La llamada hermenéutica analógica desarrollada por Mauricio Beuchot tiene precisamente por sexto objetivo equilibrar el sentido literal y el alegórico, y espera conseguir entre otros efectos el de favorecer la convergencia de lo sincrónico y lo diacrónico, de lo sistemático y lo histórico: "No se considera válida sólo una interpretación, como en el positivismo (lo cual es como si no se pudiera interpretar); tampoco se consideran válidas todas las interpretaciones, como en el romanticismo y la posmodernidad (lo cual es como si no se pudiera interpretar). Hay más de una interpretación válida, pero no todas lo son, y el conjunto de las válidas observa cierto orden o gradación de mejor a peor, y tras eso comienzan a ser falsas [...]. Es decir, entre los extremos de la hermenéutica unívoca y la hermenéutica equívoca, [la hermenéutica analógica] encuentra un medio, que logra poniendo un límite (prudencial)" (Beuchot, 2008: 25-26).

${ }^{23}$ Sobre la postura de diversas escuelas teóricas del XX hacia el binomio intentio auctoris / intentio operis, sea cual fuere la nomenclatura que usaran, me remito a lo expuesto en Montes Doncel, 2006: 166 y ss.
} 
Si los críticos erramos, pues, que al menos esto suceda a causa de nuestra incapacidad o falta de competencia, y nunca porque nos hayamos permitido una lectura tendenciosa y partidista. Las tesis éticas de Hirsch suponen fundamentalmente la refutación a autores que, en la línea de Gadamer, estiman que las peculiares características del lenguaje literario — polivalencia, sugerencia—, y también su condición pragmática de diferido, propician un cambio en la relación entre intérprete y texto (Gadamer, 1992). Pero la ambigüedad inherente al mensaje artístico dimana del individuo que lo concibió; el mundo creado no existe con independencia de su creador y por tanto, si la obra está bien construida, solo será ambigua en la medida en que su autor quiso que lo fuera. Se admite que un texto pueda dar cabida a más de una lectura, pero esto no equivale a conceder que quepan lecturas infinitas, sino solo tantas como su autor estableció (vid. Eco, 1985). Atendiendo a la definición y terminología tradicional, sensus litteralis y sensus spiritualis parecen excluyentes; en cambio, en una acepción más amplia, "sentido filológico" y "sentido alegórico" se superponen y no tienen por qué excluirse. Cotéjense las nociones de "significado" y "sentido" en Lázaro Carreter (1990). De hecho, pocos pueden defender, desde presupuestos generativistas, la pertinencia de reconocer un grado cero literal, netamente separado de su dimensión figurativa, pues sería tanto como sancionar el divorcio entre forma y contenido.

\section{Un ejemplo de lectura excesiva y anacrónica: el soneto «Otro aquí no se ve que, frente a frente» de Francisco de Aldana}

Como estipula José Lara Garrido (Aldana, 2000: 14 y ss.), editor de la obra de Aldana, dos lugares comunes entre sí vinculados vertebraron en el siglo XX la bibliografía que se ocupa del escritor extremeño: el primero, ponderar el dato de que su muerte se produjera en la histórica jornada de Alcazarquivir, y extraer de él la consecuencia de que la poesía del capitán Aldana cifra la falacia patética o sobredeterminación, si queremos emplear noménclator psicoanalítico, del devenir de su pensamiento y de una trayectoria vital sobre la cual disponemos de parvos datos (¿por qué los críticos no sienten la obsesiva necesidad de mencionar, cada vez que analizan un poema de Garcilaso, que el autor murió a causa de las heridas recibidas en su temerario asalto a la fortaleza de Muy, siendo por cierto aún más joven de lo que lo era Aldana en el momento de su óbito?).

En segundo lugar, se ha encarecido la «Epístola a Arias Montano», composición que concentra en buena cuantía la atención de los estudiosos, en calidad de "testamento poético" de El Divino, como si a este le hubiese sido dado prever, en el momento en que la elaboró, que iba a morir en el curso de una batalla once meses después. Otro de los textos de Aldana que ha convocado más interés en la crítica es el que ahora enjuiciamos, numerado como el XLV, sobre todo porque posee una porosidad semántica que lo ha hecho apto también, igual que el poema a Montano, para abonar en uno u otro sentido las tesis biografistas y el cierto halo de malditismo en que se ha envuelto a su artífice:

Otro aquí no se ve que, frente a frente, animoso escuadrón moverse guerra, sangriento humor teñir la verde tierra, 
No me detendré en cuestiones estilísticas o dispositivas del texto que han sido ya tratadas por la crítica, como el recurso a la compositio loci ignaciana en la presentación de los cinco sentidos, ordenada y en gradación de intensidad creciente ${ }^{24}$ : "palpar" heridas resulta más impresionante que beber o gustar agua corrompida; este acto, a su vez, más impresionante que el de oler la carne quemada, como olerla es peor que oír el fragor del combate, y que contemplarlo. En este aspecto, el poema utiliza los mecanismos de la evidentia o hipotiposis, esto es, de la descripción de "lo abstracto de hechos, personas o cosas [...] mediante lo concreto y perceptible, acentuando los matices de plasticidad" (Platas Tasende, 2011: 321); no obstante, como ya algunos han anotado, se evita el apóstrofe y no se emplea en ningún momento la primera persona gramatical (Rivers, 1955a: 604; Ruiz Silva, 1981: 122; García, 2010: 438). Sí registramos el tiempo presente y deícticos de proximidad: aquí, este, acá; "Otro aquí no se ve" equivale a "Otra cosa aquí no se ve". Respecto a la expresión "moverse guerra", Autoridades recoge en mover la acepción de dar principio a alguna cosa, en lo físico o en lo moral, "como mover guerra, mover discordia".

Tocante a las licencias métricas, y justamente en los versos donde se habla del sentido del oído, Aldana usa la diéresis en procura de ratificar este contenido de estruendo con la pronunciación entrecortada por la ruptura de los diptongos. Los valores rítmicos logrados mediante la acentuación de los últimos versos no pasaron inadvertidos para Rivers (1955a: 604, 1955b: 21) ni para Ruiz Silva (1981: 121).

Pero centrándonos en el plano hermenéutico, que es el que aquí nos interesa, comprobamos que los exegetas contemporáneos se polarizan en dos tendencias: los que en la primera mitad del siglo pasado ven en el poema el paradigma de una apología del Imperio español y de la gloria castrense, y aquellos que, sobre todo en las últimas décadas del XX y en el XXI, lo consideran un singular modelo de antibelicismo avant la lettre. Los primeros leen el verso final en su recto sentido mientras que los segundos lo estiman irónico. De acuerdo con Lara Garrido, Elias L. Rivers “adopta una posición equidistante entre las anteriores" (Aldana, 2000: 344n), y creo que, en efecto, el análisis firmado por

\footnotetext{
24 “Composición de lugar” es, incluso, el título que Elias L. Rivers (1955b) dio a su análisis del poema. Vid. también Green,
} 1969, IV: 215-216, y Walters, 1988: 106-107. 
este autor hace más de sesenta años sigue siendo uno de los más lúcidos y ayuno de prejuicios que se han efectuado sobre el soneto.

Entre quienes se adscriben a la primera tendencia figuran Luis Felipe Vivanco en 1940, en el 43 Rodríguez Moñino, Pedro de Lorenzo en 1944 o Lefebvre en $1953^{25}$. El filólogo alemán Vossler marca en 1944 la inflexión hacia un cambio de postura hermenéutica relativo al poema, apuntando a su posible naturaleza "humorística y sarcástica" (Vossler, 2000: 111). Abogan por la lectura en clave irónica Carlos Ruiz Silva (1981), Salstad (1982), Walters (1988) o, más recientemente, Fox (2005), abanderados de la "modernidad" del soneto. Asimismo se sumarían a esta segunda opción críticos tan solventes como Cristóbal Cuevas (1982), Julio Neira (1990) y, ya en el siglo XXI, Russell P. Sebold (2006).

Al margen de un análisis del tipo del de Dian Fox, que representa ya la deriva exegética postmoderna, en su caso hacia una "lectura de género" de corte pseudopsicoanalítico, es Carlos Ruiz quien adopta una posición actualizadora más maximalista. Espigo algunas de sus afirmaciones:

A nosotros nos parece muy clara la posición de Francisco de Aldana. Condenado a una vida militar, que en su fondo repugnaba, el poeta se sirve de una sangrienta ironía para mostrar el divorcio entre la postura "oficial": el heroísmo, la nobleza de la milicia, el honroso fin y la realidad que tantas veces sintió en su propio cuerpo y en su propio espíritu [...]. Y es el último verso precisamente — con su rotunda acentuación yámbica - el que remata y da conciencia crítica a toda la composición. [...]

La modernidad de Aldana se nos aparece aquí de una manera insoslayable, pues la crítica parte no de un hombre alejado de la estrategia militar, sino precisamente de un soldado. El que un poeta del siglo XVI, en plena gloria y poderío del imperio español, se atreva a escribir un soneto como éste es algo verdaderamente insólito. La amargura terrible que rezuma el poema no es, sin embargo, una mera actitud impulsiva y pasajera, sino una asunción muy meditada del problema de la guerra, reflejada en la forma impersonal y objetiva adoptada en la construcción del soneto (Ruiz Silva, 1981: 121-122. Subrayados míos).

Parece indiscutible que nunca podremos saber, a través de su obra de creación (y no contamos con otros testimonios definitivos al respecto), cómo repugnaba o gustaba Aldana en su fondo la vida militar, lo que sentía en su propio espíritu o cuánto había meditado la asunción sobre el problema de la guerra que según Carlos Ruiz vertió en el poema XLV. Del rastreo en su obra poética tampoco se extraen datos que permitan corroborar la lectura antifrástica del último verso. En este sentido los estudiosos han expurgado los textos de El Divino privilegiando la «Epístola a Arias Montano», los «Pocos tercetos escritos a un amigo» y el soneto «Mil veces callo que romper [deseo]» en tanto índices de desengaño del sujeto lírico, instancia ficticia en la que la crítica romántica y posromántica se obstina en seguir buscando un correlato del autor real. Bien es cierto que el hablante poético puede actuar y a menudo actúa como metonimia del yo empírico, según ha estudiado la pragmática de la lírica (vid., por ejemplo, Combe, 1999), pero no habría que perder de vista que se trata siempre de entidades diferentes, y que los poetas y lectores prerrománticos distinguían con mayor nitidez que nosotros el alto grado de convencionalidad de esta categoría.

\footnotetext{
${ }^{25}$ Anoto un comentario representativo de los de este jaez: “[...] después de describirnos la guerra en todos sus horrores correspondientes a los cinco sentidos corporales: ver, oír, oler, gustar y tocar, y cuando esperábamos su más rotunda reprobación humana, hace su elogio en un solo verso final soberbio y sorprendente" (Vivanco, 1940: 308).
} 
Por su parte el prestigioso hispanista Russell P. Sebold, al que debemos tantas páginas brillantes acerca de nuestra literatura (especialmente, a mi juicio, las que versan sobre la condición realista de la narrativa romántica del siglo XIX), incurre con inusitada virulencia en los más manidos tópicos de la leyenda negra española, e incluso en inexactitudes históricas, en su trabajo sobre Aldana ${ }^{26}$. Contraponiendo «Otro aquí no se ve que, frente a frente» con «Pocos tercetos escritos a un amigo», donde sale "a relucir la arrogancia del militar" (Sebold, 2006: 81), manifiesta Sebold:

Mas en el mismo Aldana se da la ironía de otra visión tan radicalmente disidente de la vida militar, que podría ser una de las más discrepantes protestas antimilitares del siglo XXI. [...] La aplastante ironía del endecasílabo final deriva de las insinuaciones de los versos precedentes (Sebold, 2006: 81).

En su voluminosa monografía de 2010 dedicada a Aldana enhebra Miguel Ángel García exhaustivamente las interpretaciones que hasta esa fecha se habían publicado de «Otro aquí no se ve que, frente a frente» (García, 2010: 438-453). Aunque se manifiesta menos radical que Carlos Ruiz y Russell P. Sebold, también él se alista en las filas de los partidarios de la lectura irónica, y su exposición cae en ciertas contradicciones:

En nuestra lectura el último verso no supone ningún "alzamiento", ninguna disculpa o alabanza de los horrores descritos hasta llegar a él. Este "choque final" desautoriza, por el contrario, toda posible satisfacción en la violencia que le antecede [...]. A esta desautorización parece contribuir a la vez el animismo estrictamente laico, que en «Pocos tercetos» llevaba a resaltar, de acuerdo con la articulación público / privado, el mérito y el "honroso sudor" del soldado. Obviamente, cuando en el soneto que nos ocupa se alude al "honroso fin" tras el que corre la gente cuando entra en batalla, lo que habla, en consonancia con el verso final, no es sino la ironía. También se puede afirmar que el Aldana sustancialista u organicista nunca va a promover la deslegitimación de la guerra. Todo lo contrario, porque sencillamente la guerra está sacralizada, sus horrores tienen pleno sentido. [...]

[el soneto] desde luego no puede leerse en sentido literal [...].

Más que denuncia hay distanciamiento con respecto a los horrores que se han experimentado en carne propia, y sobre todo con respecto a un modo históricamente determinado la gloria [...]. Lo cual no permite convertir a Aldana precisamente en un adelantado del pacifismo moderno. Si condena la guerra (al mismo tiempo que la preconiza como resorte del Imperio español [...]) es desde la ideología de su coyuntura histórica concreta, desde el horacianismo "a lo divino" al final o incluso desde el humanismo y su idea de concordia (García, 2010: 442-445).

No me queda claro si, en opinión de Miguel Ángel García, Aldana defiende o denuncia la guerra. Tal vez lo que quiere decir este crítico es que el texto es ambiguo (hipótesis que por cierto yo no comparto), pero no lo dice; insiste en su carácter irónico, y, por otro lado, el establecimiento de un hiato entre el "humanismo" y las armas (García cita el concepto de concordia humanista explicado por Soria Olmedo) se me antoja como mínimo espinoso. Parece superfluo tener que recordar la larga lista de los filósofos y escritores que han tomado parte en acciones de guerra y no se han mostrado nunca arrepentidos de ello, desde Sócrates, que luchó en numerosos combates durante diez años (Potidea,

\footnotetext{
${ }^{26}$ He aquí su diatriba contra Felipe II: "El tono del país lo fija el grisáceo, devoto y nada heroico covachuelista que tiene por rey. El único rayo de esperanza para el imperio heredado de Carlos V lo ve Aldana en el Habsburgo bastardo, don Juan de Austria, quien se había llevado la resonante victoria de Lepanto contra los infieles en 1571, no en el inerme y prosaico hermano legítimo de éste, Felipe II" (Sebold, 2006: 82). Y añade, en referencia a la participación de Aldana en el visionario proyecto del rey portugués que a la postre acabaría con la vida del alacre militar español: "Frente a este hombre sin hombría, ¿podría Sebastián llevarse otra victoria para la fe semejante a la del príncipe Juan?” (Sebold, 2006: 82). En cuanto a las incorrecciones, al humanista extremeño Benito Arias Montaño lo hace originario de Sevilla (Sebold, 2006: 87).
} 
Delio, Anfípolis), hasta Tolstoi (Guerra de Crimea), ensalzador de la pasión guerrera y de la vida militar en algunos de sus textos (Guerra y paz) y nada sospechoso tampoco de carecer de sensibilidad y preocupaciones éticas; pasando claro está por Cervantes, quien se jacta en el celebérrimo prólogo del Quijote del 15 de haber ganado su manquez en "la más alta ocasión que vieron los siglos presentes ni esperan ver los venideros".

Se han esgrimido a la largo de la Historia justificaciones políticas, jurídicas y religiosas para legitimar la guerra, pero el siglo XX, el siglo del advenimiento del pacifismo teórico (y por supuesto no menos violento en la praxis que los anteriores), también engrosó esta nómina con ejemplos de intelectuales que se dicen orgullosos de haber luchado en el frente por su patria o por sus convicciones. Frente a un Remarque podemos citar a un Wittgenstein, que combatió también en la Primera Guerra Mundial, o a un Claudio Guillén, que se alistó en las Fuerzas Libres Francesas en la Segunda, y cientos de casos más ${ }^{27}$.

Algunos autores posteriores al ecuador del siglo XX hacen hincapié en la complejidad y en la plurivalencia antes que en un posible sensus irónico de «Otro aquí no se ve que, frente a frente». Antonio Prieto había deducido de «Pocos tercetos escritos a un amigo» que "en ningún punto de su rebelde desengaño existe asomo de renuncia militar. Todo lo contrario: los tercetos van deslizándose en un latido de creciente afirmación de sí y de rabiosa condena de los que andan allá 'buscando introducción por diestro modo"' (Prieto, 1984: 272-273). Años más tarde, y en referencia al soneto, escribirá que una amarga ironía lo baña de ambigüedad "porque es triste que la guerra, vecina de la muerte, sea el estado que enseñe al hombre su caducidad [...]" (Prieto, 1991: 705). Para Lara Garrido se trata de un caso de ambigüedad radical, "ya que no resulta íntegramente una afirmación ni una negación" (Lara Garrido, 2000: 309). En cuanto a Rivers, firma en su libro de 1955 unas primeras apreciaciones, muy en la onda de la Estilística genética, en las que aúna los textos de ficción con la trayectoria vital del poeta:

Este soneto de Aldana, juzgado a la luz de su desarrollo espiritual, revela lo que era un efectivo conflicto en la mente de nuestro soldado-poeta; por mucho que se esforzara, tenía evidente dificultad en aceptar un ideal exclusivamente militarista, pues en el fondo se daba cuenta de que, en efecto, existía una vida mucho más noble, de la que había tenido en Florencia una prueba inolvidable (Rivers, 1955a: 72. Subrayados míos).

Ese mismo año, sin embargo, aparece en Clavileño un artículo dedicado al poema donde se leen las siguientes afirmaciones, que suscribo:

El problema biográfico es fascinador, pero no debe confundirse con el problema literario del soneto como objeto de arte. [...] la crítica literaria propiamente dicha no puede examinar la arcana génesis psicológica del poema, sino solo su modo de ser como objeto lingüístico y artístico (Rivers, 1955b: 20).

\footnotetext{
27 Vid. el libro de Tovar Paz La delgada línea roja. Videt ex ordine bella (Tovar Paz, 2012), análisis de la película de Terrence Malick subtitulado con un verso que se adapta de la Eneida; cabría traducirlo por "contempla la secuencia de las batallas", y se localiza en el momento en que el héroe ve las escenas de sus propias gestas que decoran el templo de Cartago (y, como arriba se explica, la evidentia preside también el poema de Aldana). Javier Tovar allega los ejemplos de filósofosguerreros encarnados por Sócrates y Wittgenstein (quien inspira el nombre del protagonista del filme).
} 
De las lecturas de época: intentio auctoris versus intentio operis. Sobre un soneto de F. de Aldana

Y, al igual que Lara casi cincuenta años después, concluye que

[en] la violencia que se descarga en el último verso [...] está el sentido total del soneto, que es una paradoja irreductible. En la guerra, la vida es más vida y la muerte más muerte; es a la vez vil y gloriosa. Dicho de otro modo, este soneto no es una afirmación, ni una negación, lógica: abarcando a Escila y Caribdis al mismo tiempo, es la presentación de una situación humana en toda su fervorosa amplitud y complejidad irracional (Rivers, 1955b: 21).

Efectivamente, la clave reside no en la ironía ni en la antanaclasis, sino en la paradoja y la antítesis, que se aplican aquí a la guerra como a veces al amor, a la muerte o a otros temas literarios, sin que ello implique en absoluto que el poeta reniegue de esos sentimientos o situaciones. Componen también oxímoros, antes de llegar al verso último, los sintagmas "dulce son” y "süave olor”, y tampoco tienen por qué albergar ambigüedad. En mi opinión el verso decimocuarto entraña una paradoja, no una dilogía: no quiere significar una cosa y la contraria, no busca transmitir una concepción de la batalla como digna e indigna al mismo tiempo. La guerra, según el sensus litteralis de este poema, constituye el más noble estado del hombre, aunque a dicho estado haya que llegar por medio de un sufrimiento terrible. La asunción de la antífrasis en el verso final deviene una misreading anacrónica procedente de la mentalidad de hombres contemporáneos que estos críticos proyectan en la creación de un hombre del siglo XVI, que vivió y murió muchos siglos antes de que floreciese teoría pacifista alguna.

Francisco de Aldana fue, como Don Juan Manuel, como los grandes poetas profanos del Cuatrocientos, Santillana y Manrique, como sus coetáneos Garcilaso de la Vega, Hernando de Acuña o Gutierre de Cetina, o como su seguidor Fernández de Andrada, soldado profesional, y nunca abandonó este oficio. De hecho, y a pesar de lo relativamente extenso de su producción, gran parte de la cual se ha perdido, la literatura constituyó para él una actividad secundaria y no llegó a publicar en vida. Tal empresa, como de todos es sabido, corrió a cargo de su hermano Cosme. Ni los datos biográficos que poseemos, ni el análisis inmanente y filológico ni la coherencia interna de la composición autorizan una lectura antibelicista. Y más contradice aún dicha tesis el conocimiento del contexto histórico de su autor, esto es, el de un guerrero del Imperio Español del Renacimiento.

\section{Referencias bibliográficas}

ALDANA, F. de (2000). Poesías castellanas completas. Madrid, Cátedra, edición de J. Lara Garrido. ALÍN, J. M. (Ed.) (1991). Cancionero tradicional. Madrid, Castalia.

BARTHES, R. (1963). Sur Racine. París, Seuil.

BARTHES, R. (1966). Critique et verité. París, Seuil.

BARTHES, R. (1977 [1967]). «The death of the author». En Image, music, text, Nueva York, Fontana, 142-148.

BECERRA MAYOR, D. (2006). «El impacto burgués y la ambigüedad de los linajes de Calisto y Melibea». En Verba hispánica, 14, pp. 21-37. 
BEUCHOT, M. (2008). «Los presupuestos filológicos de la hermenéutica analógica». En J. Esteban Ortega (Ed.), Hermenéutica analógica en España, Valladolid, Universidad Europea Miguel de Cervantes, 21-29.

BOOTH, W. C. (1974 [1961]). Retórica de la ficción. Barcelona, Bosch, 1974.

CAMPA MARCÉ, C. (2009). «Réquiem por un campesino español: la tragedia de la mala conciencia (¿Mosén Millán, padre de Paco el del Molino?)». En Espéculo. Revista de estudios literarios, 41. COMBE, D. (1999 [1996]). «La referencia desdoblada: el sujeto lírico entre la ficción y la autobiografía». En F. Cabo Aseguinolaza (Coord.), Teorías sobre la lírica, Madrid, Arco/Libros, 126-153.

DÍEZ DE REVENGA, F. J. (2001-2002). «El Poema de Mio Cid y su proyección artística posterior (ficción e imagen)». En Estudios Románicos, 13-14, 59-85.

DOLEŽEL, L. (1997). «Mímesis y mundos posibles». En A. Garrido Domínguez (Coord.), Teorías de la ficción literaria, Madrid, Arco/Libros, 69-94.

ECO, U. (1985 [1962]). Obra abierta. Forma e indeterminación en el arte contemporáneo. Barcelona, Ariel.

ECO, U. (1992 [1990]). Los límites de la interpretación. Barcelona, Lumen.

FERNÁNDEZ DE ANDRADA, A. (2006). «Epístola moral a Fabio y otros escritos». Barcelona, Galaxia Gutenberg, edición de D. Alonso, estudio preliminar de J. F. Alcina y F. Rico.

FOX, D. (2005). «"Frente a frente”: Francisco de Aldana and sublimations of desire». En Caliope: Journal of the Society for Renaissance and Baroque Hispanic Poetry, 11-1, 65-85.

GADAMER, H. G. (1992 [1977]). Verdad y método. Salamanca, Ediciones Sígueme.

GARCÍA, M. Á. (2010). «Sin que la muerte al ojo estorbo sea». Nueva lectura crítica de Francisco de Aldana. Mérida, Editora Regional.

GARCÍA LORCA, F. (1960). Obras completas. Madrid, Aguilar.

GARRIDO DOMÍNGUEZ, A. (1993). El texto narrativo. Madrid, Síntesis.

GENETTE, G. (1989 [1972]). Figuras III. Barcelona, Lumen.

GOYTISOLO, J. A. (2009 [1961]). Poesía completa. Barcelona, Lumen, edición de C. Riera.

GREEN, O. H. (1969). España y la tradición occidental. El espíritu castellano en la literatura desde El Cid hasta Calderón. Madrid, Gredos, 4 vols.

HIRSCH, E. D. Jr. (1997 [1972]), «Tres dimensiones de la hermenéutica». En J. Domínguez Caparrós (Coord.), Hermenéutica, Madrid, Arco/Libros, 137-158.

INGARDEN, R. (1989). «Concreción y reconstrucción». En W. Warning (Ed.), Estética de la recepción, Madrid, Visor, 33-53.

LARA GARRIDO, J. (2000). «"Palma de Marte” y "Lauro de Apolo”: la poesía del "oficio militar" en Francisco de Aldana y Cristóbal de Virués». En AAVV, La espada y la pluma. Il mondo militare nella Lombardia spagnola cinquecentesca. Atti del Convegno Internazionale di Pavia 1997, Luca, Mario Boroni, 281-346. 
De las lecturas de época: intentio auctoris versus intentio operis. Sobre un soneto de F. de Aldana

LÁZARO CARRETER, F. (1990). «El poema y el lector. El poema lírico como signo». En De poética y poéticas, Madrid, Cátedra, 15-33.

LEFEBVRE, A. (1953). La poesía del capitán Aldana (1537-1578). Universidad de Concepción.

LORENZO, P. de (1944). «La razón poética del capitán Aldana». En Escorial, XV, 45, 303-310.

MAINER, J.-C. (2000). Historia, literatura, sociedad (y una coda española). Madrid, Biblioteca Nueva.

MARTÍN JIMÉNEZ, A. (2014). «Intentio auctoris e intentio operis: intención manifiesta e intención encubierta en Cervantes y Avellaneda». En Monteagudo, 19, 161-175.

MARTÍNEZ BONATI, F. (1987). «Mensajes y literatura». En AAVV, La crisis de la literariedad, Madrid, Taurus, 65-97.

MARTÍNEZ FERNÁNDEZ, J. E. (2001). La intertextualidad literaria. Madrid, Cátedra.

MONTES DONCEL, R. E. (2000). «Elipsis no temporal: tipología en las literaturas europea y americana». En AAVV, Homenaje a la Profesora Carmen Pérez Romero, Cáceres, Facultad de Filosofía y Letras, 233-248.

MONTES DONCEL, R. E. (2006). La tematología comparatista en la literatura y el cine (El aristócrata en su decadencia). Madrid, Pliegos.

MONTES DONCEL, R. E. (2008). «La Deconstrucción. Fundamentos y posibilidades de proyecciones prácticas». En EPOS. Revista de Fiología, XXIV, 243-261.

MONTES DONCEL, R. E. (2016). «Tipología y funciones en las voces y silencios en el cine de ficción. Interferencias con la literatura». En S. Bouso González, P. Couto Cantero, R. Núñez Ramos y J. Ma . Paz Gago (Eds.), La pantalla ficticia. Literatura y tecnologías de la comunicación, Madrid, Pigmalión, 213-348.

MONTES DONCEL, R. E., y REBOLLO ÁVALOS, Mª J. (2008). «En la encrucijada de la traducción literaria: actualización bibliográfica y aplicaciones didácticas». En Revista de Filología de la Universidad de La Laguna, 26, 151-166.

MORTARA GARAVELLI, B. (1991). Manual de retórica. Madrid, Cátedra.

NEIRA, J. (1990). Francisco de Aldana. Mérida, Editora Regional.

PARELLO, V. (2007). «Don Diego Coronel o la figura de un converso encumbrado». En Sociocriticism, XXII, 1 y 2, 97-118.

PICARD, R. (1965). Nouvelle critique ou nouvelle imposture. París, J.-J. Pavert.

PLATAS TASENDE, A. M. a (2011 [2004]), Diccionario de términos literarios, Madrid, Espasa.

POEMA DE MIO CID (1981). Poema de Mio Cid. Madrid. Cátedra, edición de C. Smith.

POZUELO YVANCOS, J. Mª (Ed.) (1999). Antología poética de Francisco de Quevedo. Madrid, Biblioteca Nueva.

PRIETO, A. (1984). «Francisco de Figueroa. Francisco de Aldana». En Poesía española del siglo XVI. I. Andáis tras mis escritos, Madrid, Cátedra, 233-283.

PRIETO, A. (1991). «Francisco de Aldana». En J. M Jover Zamora, Historia de España, Madrid, Espasa-Calpe, 703-709. 
QUEVEDO, F. de (1999). Obra poética I. Madrid, Espasa Calpe, edición de I. Arellano.

QUEVEDO, F. de (2001). La vida del Buscón. Barcelona, Crítica, edición de F. Cabo Aseguinolaza. REDONDO, A. (2002 [1971]). «Del personaje de don Diego Coronel a una nueva interpretación de $E l$ Buscón». En V. Roncero López y J. E. Duarte Lueiro (Eds.), Quevedo y la crítica a finales del siglo XX (1975-2000), Pamplona, Ediciones de la Universidad de Navarra, vol. 2, 191-204.

RIVERS, E. L. (1955a). Francisco de Aldana, el Divino Capitán. Badajoz, Diputación Provincial. RIVERS, E. L. (1955b). «Composición de lugar», en Clavileño, año VI, mayo-junio, n 33, 19-21. RODIEK, Ch. (1995). La recepción internacional del Cid. Madrid, Gredos.

RODRÍGUEZ MOÑINO, A. (1943). El capitán Francisco de Aldana, poeta del siglo XVI (15371578). Valladolid, Colegio Universitario de Santa Cruz.

RODRÍGUEZ RODRÍGUEZ, R. (1979). «Observaciones sobre el soneto "Miré los muros de la patria mía"». En Anuario de estudios filológicos, 239-249.

RUIZ SILVA, C. (1981). Estudios sobre Francisco de Aldana. Universidad de Valladolid, Secretariado de Publicaciones.

SALSTAD, L. (1982). «Another look at Francisco de Aldana's "Otro aquí no se ve"». En Romance Notes, 22-23, 335-340.

SCHLEIERMACHER, F. D. E. (2000 [1813]). Sobre los diferentes métodos de traducir. Madrid, Gredos.

SEBOLD, R. P. (2006). «Francisco de Aldana: su lucha existencial ante "la risa de su llanto"». En Salina. Revista de lletres, 20, 81-90.

SENDER, R. J. (2018). Réquiem por un campesino español. Barcelona, Austral, edición de A. A. Gómez Yebra.

TOBAR QUINTANAR, M. ${ }^{\mathrm{a}}$ J. (2002). "“Miré los muros de la patria mía” y la reescritura de Quevedo». En La Perinola. Revista de investigación quevediana, 6, 239-261.

TOVAR PAZ, J. (2012). La delgada línea roja. Videt ex ordine bella (Contempla la secuencia de las batallas). Madrid, Akal.

VILLALONGA, L. (1985). Bearn o la sala de las muñecas. Madrid, Cátedra, edición de J. Vidal Alcover.

VILLANUEVA, D. (1994). Estructura y tiempo reducido en la novela. Barcelona, Anthropos.

VIVANCO, L. F. (1940). «El sentido del Imperio en la lírica del siglo XVI». En L. Rosales y L. F. Vivanco (Eds.), Poesía heroica del Imperio, Barcelona, Jerarquía, I, IX-XXX.

VOSSLER, K. (2000 [1941]). «Francisco de Aldana». En La soledad en la poesía española, Madrid, Visor, 177-191.

WALTERS, D. G. (1988). The Poetry of Francisco de Aldana. Londres, Támesis.

WIMSATT, W. K., y BEARDSLEY, M. (1954). «The Intentional Fallacy» y «The Affective Fallacy». En The Verbal Irony. Studies in the Meaning of Poetry, University of Kentucky Press, 3-18 y 2139. 